\title{
Pengelolaan Alokasi Dana Desa Pada Desa Jajaran Baru I Kecamatan Megang Sakti Kabupaten Musi Rawas
}

\author{
Yayuk Marliza', Selvina Ibrahim ${ }^{2}$ \\ ${ }^{1}$ Fakultas Ekonomi Universitas Musi Rawas, Marlizayayuk77@gmail.com \\ ${ }^{2}$ Fakultas Ekonomi Universitas Musi Rawas, Selfinaajalah@gmail.com
}

\begin{abstract}
The aim of this study was to analyze the Management of Village Fund Allocation in Jajaran Baru I Village. The research method useddescriptive research namely research conducted to determine the value of independent variables, either one or more variables without making comparisons or connecting with other variables. The data used were primary and secondary data. Data collection techniques were in the form of interviews and observation. The data analysis used qualitative analysis and technical analysis using descriptive data analysis. The results achieved in this study wasManagement of Village Fund Allocation in Jajaran Baru I Village in the planing, implementation, administration, reporting and accountability stage had been carried aut properly. For the development and supervision phases according to domestic ministry regulation no 113,2014 and regent decision no $157 / K P T S / D P M D / 2017$. It was concluded that there were delays in the disbursement implementation stage $A D D$ so that it affected the reporting and accountability stage.
\end{abstract}

Keywords: Management, Village Fund Allocation

\section{ABSTRAK}

Tujuan penelitian ini adalah untuk menganalisis Pengelolaan Alokasi Dana Desa Pada Desa Jajaran Baru I Kabupaten Musi Rawas. Metode penelitian yang digunakan adalah penelitian deskriptif, yaitu penelitian yang dilakukan untuk mengetahui nilai variabel mandiri, baik satu variabel atau lebih tanpa membuat perbandingan atau menghubungkan dengan variabel yang lain. Data yang digunakan adalah data primer dan sekunder. Teknik pengumpulan data yang digunakan adalah wawancara dan observasi. Analisis data yang digunakan adalah analisis kualitatif dan Teknis Analisis menggunakan analisis data deskriptif. Hasil yang dicapai dalam penelitian ini adalah Pengelolaan ADD Pada Desa Jajaran Baru dalam tahapan perencanaan, pelaksanaan, penatausahaan, pelaporan dan pertanggungjawaban telah dilaksanakan dengan baik. Untuk tahapan pembinaan dan pengawasan telah sesuai berdasarkan Peraturan Menteri Dalam Negeri Nomor 113 Tahun 2014 dan Keputusan Bupati Nomor 157/KPTS/DPMD/2017. Disimpulkan bahwa adanya keterlambatan dalam tahapan pelaksanaan pencairan ADD sehingga berpengaruh terhadap tahapan pelaporan dan pertanggungjawaban.

Kata kunci: Pengelolaan, Alokasi Dana Desa

\section{A. PENDAHULUAN}

Pengelolaan keuangan desa merupakan hal yang penting karena semua desa menerima Dana Desa dan Alokasi Dana Desa. Dana Desa (DD) merupakan kewajiban Pemerintah Pusat untuk mengalokasikan anggaran transfer di dalam APBN sebagai wujud pengakuan dan penghargaan negara kepada desa. Dana Desa adalah dana yang bersumber dari APBN yang diperuntukan bagi desa yang ditransfer melalui APBD Kabupaten/Kota dan digunakan untuk mendanai penyelenggaraan pemerintah, pelaksanaan pembangunan, pembinaan dan pemberdayaan masyarakat (Peraturan Menteri Desa, Pembangunan Daerah Tertinggal dan Transmigrasi Republik Indonesia Nomor 22 Tahun 2016 : Pasal 1). 
Alokasi Dana Desa (ADD) adalah dana perimbangan yang diterima kabupaten/kota dalam Anggaran Pendapatan dan Belanja Daerah Kabupaten/Kota setelah dikurangi Dana Alokasi Khusus. Alokasi Dana Desa merupakan kewajiban Pemerintah Daerah Kabupaten/Kota untuk mengalokasikan anggaran desa yang diambil dari Dana Bagi Hasil (DBH) dan Dana Alokasi Umum (DAU) yang merupakan bagian dana perimbangan. Besaran ADD masing-masing Kabupaten/Kota setiap tahun adalah 10\% (Sepuluh Persen) dari DBH dan DAU yang dialokasikan dalam APBD Kabupaten/Kota. Pengalokasian setiap desa dan tata cara penggunaan ADD diatur melalui Peraturan Bupati/Walikota yang ditetapkan setiap tahun (Peraturan Bupati Musi Rawas Nomor 4 Tahun 2017 : Pasal 1)

Alokasi Dana Desa yang diterima Pemerintah Desa dari Pemerintah Kabupaten/Kota sebanyak $30 \%$ dipergunakan untuk biaya operasional penyelenggaraan pemerintah desa dan BPD sedangkan $70 \%$ dipergunakan untuk pemberdayaan masyarakat desa seperti pembangunan sarana dan prasarana ekonomi desa, pemberdayaan dibidang pendidikan dan kesehatan, pemberdayaan ekonomi masyarakat serta bantuan keuangan kepada lembaga masyarakat desa. (Soleh dan Rochmansjah, 2015)

Berdasarkan Keputusan Bupati Musi Rawas Nomor 157/KPTS/DPMD/2017 tentang Penetapan Besaran Alokasi Dana Desa Kabupaten Musi Rawas menerima anggaran Dana Desa (DD) dari APBN ditransfer melalui APBD Kabupaten Musi Rawas Tahun 2017 sebesar Rp. 146,5 milyar dengan jumlah desa yang menerima sebanyak 186 desa. Sedangkan Alokasi Dana Desa (ADD) yang dianggarkan oleh pemerintah Kabupaten Musi Rawas Tahun 2017 sebesar Rp. 80.695.108.300,(Delapan puluh milyar enam ratus sembilan puluh lima juta seratus delapan ribu tiga ratus rupiah) dengan jumlah desa yang menerima sebanyak 186 desa yang tersebar di 14 (empat belas) kecamatan. Desa Jajaran Baru I menerima anggaran Dana Desa (DD) Tahun 2017 sebesar Rp. 836.895.000,- (Delapan ratus tiga puluh enam juta delapan ratus sembilan puluh lima ribu rupiah) dan anggaran Alokasi Dana Desa (ADD) Tahun 2017 sebesar Rp. 301.934.500,- (Tiga ratus satu juta sembilan ratus tiga puluh empat ribu lima ratus rupiah). Anggaran ADD ini digunakan untuk penghasilan tetap, tunjangan kehormatan BPD, tunjangan kepala desa dan perangkat desa, tunjangan beban bendahara desa dan asuransi perlindungan kades, perangkat, BPD dan bendaharan desa, serta operasional pemerintahan desa dan pelaksanaan empat bidang. Untuk penghasilan tetap dan tunjangan hanya dianggarkan untuk bulan januari sampai dengan juni 2017 dan selanjutnya bulan juli sampai dengan desember 2017 dianggarkan pada APBDes perubahan. Dalam Keputusan Bupati Musi Rawas Nomor 157/KPTS/DPMD/2017 Desa Jajaran Baru I tidak mendapatkan dana bantuan Pilkades dikerenakan Pemilihan Kepala Desa telah dilaksanakan pada tahun 2015 dan hanya ada 16 Desa yang memperoleh Dana Bantuan Pilkades dari 186 desa di Kabupaten Musi Rawas. Berlikut ini ditampilkan data realisasi alokasi dana desa di Desa Jajaran Baru Kabupaten Musi Rawas, yang tercantum dalam Lampiran Keputusan Bupati Musi Rawas Nomor 157/KPTS/DPMD/2017 :

Tabel Realisasi Alokasi Dana Desa Tahap I Tahun 2017 Desa Jajaran Baru I Kecamatan Megang Sakti Kabupaten Musi Rawas

\begin{tabular}{|c|l|r|}
\hline No & \multicolumn{1}{|c|}{ Rincian ADD } & Jumlah (Rp) \\
\hline 1 & Penghasilan Tetap (Siltap) & 99.000 .000 \\
\hline
\end{tabular}




\begin{tabular}{|r|l|r|}
\hline 2 & Tunjangan Kehormatan BPD & 51.300 .000 \\
\hline 3 & Tunjangan Kepala Desa dan Perangkat Desa & 36.300 .000 \\
\hline 4 & Tunjangan Beban Kerja Bendahara Desa & 2.100 .000 \\
\hline 5 & Dana Bantuan Pilkades & 0 \\
\hline 6 & $\begin{array}{l}\text { Asuransi Perlindungan Kades, Perangkat, BPD } \\
\text { dan Bendahara Desa Per Tahun }\end{array}$ & 2.700 .000 \\
\hline 7 & Pelaksanaan 4 (empat) Bidang & 110.534 .500 \\
\hline \multicolumn{2}{|c|}{ Total } & 301.934 .500 \\
\hline
\end{tabular}

Tabel Realisasi Alokasi Dana Desa Tahap li Tahun 2017 Desa Jajaran Baru I Kecamatan Megang Sakti Kabupaten Musi Rawas

\begin{tabular}{|c|l|r|}
\hline No & \multicolumn{1}{|c|}{ Rincian ADD } & Jumlah (Rp) \\
\hline 1 & Penghasilan Tetap (Siltap) & 99.000 .000 \\
\hline 2 & Tunjangan Kehormatan BPD & 71.100 .000 \\
\hline 3 & Tunjangan Kepala Desa dan Perangkat Desa & 36.300 .000 \\
\hline 4 & Tunjangan Beban Kerja Bendahara Desa & 2.100 .000 \\
\hline 5 & Dana Bantuan Pilkades & 0 \\
\hline 6 & $\begin{array}{l}\text { Asuransi Perlindungan Kades, Perangkat, BPD } \\
\text { dan Bendahara Desa Per Tahun }\end{array}$ & 111.545 .200 \\
\hline 7 & Pelaksanaan 4 (empat) Bidang & 320.045 .200 \\
\hline \multicolumn{2}{|c}{ Total }
\end{tabular}

\section{B. KAJIAN TEORI}

Berdasarkan Peraturan Menteri Dalam Negeri Nomor 113 Tahun 2014 pasal 1 pengelolaan keuangan desa adalah keseluruhan kegiatan yang meliputi perencanaan, pelaksanaan, penatausahaan, pelaporan, dan pertanggungjawaban keuangan desa, alokasi dana desa adalah dana perimbangan yang diterima kabupaten/kota dalam anggaran pendapatan belanja daerah kabupaten/kota setelah dikurangi dana alokasi khusus.

Menurut Chabib Soleh dan Heru Rochmansjah (2015:3-5) Keuangan desa didefinisikan sebagai semua hak dan kewajiban desa yang dapat dinilai dengan uang, serta segala sesuatu baik berupa uang maupun berupa barang yang dapat dijadikan milik desa berhubung dengan pelaksanaan hak dan kewajiban tersebut. Pelaksanaan semua kewenangan desa memerlukan sejumlah uang/dana yang berasal dari hasil pungutan desa berdasarkan peraturan desa, APBN, APBD Provinsi, Alokasi Dana Desa yang bersumber dari APBD Kabupaten/Kota, dana bagi hasil pajak dan retribusi kabupaten/kota.

1) Ruang Lingkup berdasarkan sifat pengelolaannya

Sifat pengelolaan keuangan desa dibagi menjadi keuangan desa yang sifatpengelolaanya dilakukan secara langsung yang berupa Anggaran Pendapatan dan Belanja Desa APBDesa dan keuangan desa yang sifat pengelolaannya dilakukan secara terpisah oleh Badan Usaha Milik Desa (BUMDesa) 
2) Asas-asas pengelolaan keuangan desa

Untuk mencapai efektifitas dan efisiensi dalam pengelolaan keuangan desa diperlukan sejumlah asas atau prinsip yang harus dijadikan pedoman. Asas atau prinsip-prinsip dimaksud adalah :

a) Asas kesatuan, yaitu asas atau prinsip yang menghendaki agar semua pendapatan dan belanja desa disajikan dalam kesatuan dokumen anggaran desa.

b) Asas universalitas, yaitu asas atau prinsip yang mengharuskan agar setiap transaksi keuangan desa ditampilkan secara utuh dalam dokumen anggaran desa

c) Asas tahunan yaitu asas atau prinsip yang membatasi masa berlakunya anggaran untuk suatu tahun anggaran.

d) Asas spesialitas, yaitu asas atau prinsip yang mewajibkan agar kredit anggaran yang disediakan terinci secara jelas peruntukannya.

e) Asas akuntabel yang berorientasi pada hasil yaitu, asas atau prinsip yang menentukan bahwa setiap kegiatan pengelolaan keuangan desa harus dapat dipertanggung jawabkan kepada masyarakat desa, sesuai dengan ketentuan perundang-undangan.

f) Asas proporsionalitas yaitu asas atau prinsip yang mengutamakan keseimbangan antara hak dan kewajiban dalam pengelolaan keuangan desa.

g) Asas profesionalitas yaitu asas atau prinsip yang mengutamakan keahlian berdasarkan kode etik dan ketentuan perundang-undangan yang berlaku.

h) Asas keterbukaan yaitu asas atau prinsip yang membuka diri terhadap hak masyarakat untuk memperoleh informasi yang benar, jujur dan tidak diskriminatif tentang pengelolaan keuangan desa dengan tetap memperhatikan perlindungan terhadap hak pribadi dan golongan.

i) Asas pemeriksaan keuangan oleh BPK yang bebas mandiri, yaitu asas atau prinsip yang memberikan kebebasan bagi BPK untuk melakukan pemeriksaan keuangan desa dengan tidak boleh dipengaruhi oleh siapapun.

j) Asas value for money yaitu asas atau prinsip yang menekankan bahwa dalam pengelolaan keuangan desa harus dilakukan secara ekonomis, efisien dan efektif.

k) Asas kejujuran yaitu asas atau prinsip yang menekankan bahwa dalam pengelolaan dana publik (termasuk APBDesa) harus dipercayakan kepada aparat yang memiliki integritas dan kejujuran yang tinggi, sehingga potensi munculnya praktek KKN dapat diminimalkan.

I) Asas pengendalian yaitu asas atau prinsip yang menghendaki dilakukannya monitoring terhadap penerimaan maupun pengeluaran anggaran pendapatan dan belanja desa (APBDesa) sehingga bila terjadi selisih (varians) dapat segera dicari penyebab timbulnya selisih tersebut.

m) Asas ketertiban dan ketaatan terhadap perundang-undangan yaitu asas yang mengharuskan bahwa pengelolaan keuangan desa wajib berpedoman kepada peraturan perundang-undangan yang berlaku.

n) Asas bertanggungjawaban, yaitu asas yang mewajibkan kepada penerima amanah atau penerima mandat untuk mempertanggungjawabkan pengelolaan dan pengendalian sumberdaya dan pelaksanaan kebijakan yang dipercaya kepadanya dalam rangka pencapaian tujuan yang telah ditetapkan. 
o) Asas keadilan yaitu asas yang menekankan perlunya keseimbangan distribusi kewenangan dan penandaannya dan atau keseimbangan distribusi hak dan kewajiban berdasarkan pertimbangan obyektif.

p) Asas kepatutan yaitu asas yang menekankan adanya suati sikap dan tindakan yang wajar dan proporsional.

q) Asas manfaat untuk masyarakat yaitu asas yang mengharuskan bahwa keuangan desa wajin digunakan atau diutamakan untuk memenuhi kebutuhan masyarakat desa.

\section{METODE PENELITIAN}

Variabel dalam penelitian ini adalah Pengelolaan Alokasi Dana Desa, yaitu keseluruhan kegiatan dalam mengelola dana perimbangan yang diterima kabupaten atau kota dalam anggaran Pendapatan dan Belanja Daerah Kabupaten atau Kota setelah dikurangi dana alokasi khusus. Proses Pengelolaan terdiri dari perencanaan, pelaksanaan, penatausahaan, pelaporan, pertanggungjawaban, pembinaan dan pengawasan.

Populasi dalam penelitian ini adalah Anggaran Pendapatan dan Belanja Desa Jajaran Baru I kabupaten Musi Rawas Tahun 2017. Penelitian ini dilakukan pada Kantor Desa Jajaran Baru I dengan alamat Jalan Dusun III Rt. 01 Desa Jajaran Baru I Kecamatan Megang Sakti Kabupaten Musi Rawas. Penelitian ini adalah jenis penelitian deskriptif, yaitu penelitian yang dilakukan untuk mengetahui nilai variabel mandiri, baik satu variabel atau lebih (independen) tanpa membuat perbandingan, atau menghubungkan dengan variabel yang lain.

Penelitian yang penulis lakukan merupakan penelitian kualitatif yang menggunakan sumber data primer dan sumber data sekunder. Sumber primer penulis dapatkan melalui wawancara dengan kepala desa dan perangkat desa Jajaran Baru I Kecamatan Megang Sakti Kabupaten Musi Rawas. Sumber sekunder, penulis dapatkan melalui dokumen-dokumen yang terkait dengan pengelolaan ADD Desa Jajaran Baru I Kecamatan Megang Sakti Kabupaten Musi Rawas Tahun Anggaran 2017 termasuk peraturan-peraturan yang terkait dengan Alokasi Dana Desa Tahun 2017.

Teknik analisis yang digunakan adalah analisis deskriptif yaitu analisis data dengan cara memberikan penjelasan dan memberikan predikat kepada variabel yang diteliti sesuai dengan kondisi yang sebenarnya. Teknik pengumpulan data yang digunakan dalam penelitian ini yaitu observasi, wawancara, dan dokumentasi.

\section{HASIL DAN PEMBAHASAN}

\section{Perencanaan}

Dalam tahapan perencanaan pada pengelolaan ADD di Desa Jajaran Baru I berawal dari Musrembangdus (musyawarah rencana pembangunan dusun) dilanjutkan ke Musrembangdesa (musyawarah rencana pembangunan desa) dimana masyarakat mengusulkan program atau kegiatan yang akan dibiayai oleh ADD, usulan program kegiatan dari masyarakat tersebut kemudian di rangking berdasarkan skala prioritas, skala kebutuhan dan ketersediaan ADD. Kemudian dibahas dan disahkan melalui pelaksana musyawarah desa dimana musyawarah tersebut diselenggarakan oleh Pemerintah Desa Jajaran Baru I yang diikuti oleh BPD dan LPM dan tokoh agama dan pemangku adat. Sebagian besar warga memenuhi undangan yang disebar dan yang menghadirinya dari setiap lapisan masyarakat 
hadir dalam pelaksanaan musyawarah tersebut. Dalam Peraturan Menteri Dalam Negeri Nomor 113 Tahun 2014 rancangan APBDes dimulai dari Musrembangdes sehingga dalam tahapan pelaksanaan Pemerintah Desa Jajaran Baru I telah mengikuti semua prosedur sesuai peraturan yang berlaku, yang lebih baik lagi Pemerintah Desa Jajaran Baru I telah memulai tahapan melalui Tahapan Musrembangdus yang seharusnya dari Musrembangdes saja.

Pelaksanaan musyawarah tersebut bertujuan untuk membahas rencana program atau kegiatan yang akan dibiayai oleh Alokasi Dana Desa tahun 2017, dan dana yang diterima oleh Pemerintah Desa Jajaran Baru I Tahap I sebelum APBDes perubahan sebesar Rp. 301.934.500,- (Tiga ratus satu juta sembilan ratus tiga puluh empat ribu lima ratus rupiah) yang penggunaannya terdiri dari Rp. 190.800.000,(Seratus sembilan puluh juta delapan ratus ribu rupiah) digunakan sebagai pembayaran penghasilan tetap dan tunjangan perangkat desa dan BPD, Rp. 56.434500,- (Lima puluh enam juta empat ratus tiga puluh empat ribu lima ratus rupiah), untuk kegiatan operasional BPD sebesar Rp. 15.500.000,- (lima belas juta lima ratus ribu rupiah), kegiatan operasional RT/RW sebesar Rp. 14.400.000,(Empat belas juta empat ratus ribu rupiah), kegiatan penyelenggara musyawarah desa Rp. 11.800.000,- (Sebelas juta delapan ratus ribu rupiah), kegiatan pengelolaan informasi desa Rp. 1.000.000,- (Satu juta rupiah) dan bidang pembinaan kemasyarakatan sebesar Rp. 12.000.000,- (Dua belas juta rupiah). (Bukti Terlampir)

Berdasarkan Keputusan Bupati Kabupaten Musi Rawas Nomor 157/KPTS/DPMD/2017 bahwa besaran Alokasi Dana Desa sebesar 30\% digunakan untuk biaya operasional penyelenggaraan pemerintah desa dan BPD dan $70 \%$ dipergunakan umtuk pemberdayaan masyarakat. Dari perencanaan tersebut telah dijelaskan bahwa 30\% ADD digunakan untuk biaya operasional penyelenggara pemerintah desa, operasional dan tunjangan bagi anggota BPD dan biaya operasional Tim Pelaksana ADD sedangkan 70\% ADD dipergunakan untuk pemberdayaan masyarakat baik dibidang pendidikan, ekonomi, kesehatan, pengembangan unit ekonomi desa, BUMDes, kelompok usaha sesuai dengan potensi ekonomi masyarakat desa, serta bantuan keuangan kepada lembaga yang ada di desa seperti LPMD, RT, PKK, Karang Taruna dan Linmas.

Proses perencanaan Desa Jajaran Baru I dilakukan dengan model partisipatif dalam kegiatan musrembang. Tim Pelaksana ADD yang dimaksud dalam perencanaan tersebut terdiri dari Kepala Desa selaku penanggungjawab operasional kegiatan dan Sekretaris Desa selaku penanggungjawab administrasi, bendahara desa selaku kepala urusan keuangan dan dibantu oleh LPM di Desa. Dalam perencanaan pembuatan Rancangan Peraturan Desa tentang APBDesa, Sekretaris Desa tidak hanya sendiri dalam mempersiapkan dan menyusun Rancangan Peraturan Desa tentang APBDesa, akan tetapi dibantu oleh staf dan kaur. Hasil evaluasi Rancangan Peraturan Desa tentang APBDesa Jajaran Baru I telah diverifikasi dan disetujui oleh Bupati melalui Camat sesuai dengan batas waktu yang ditentukan.

\section{Pelaksanaan}

Berdasarkan APBDesa yang dihasilkan pada tahap perencanaan dimulailah tahap pelaksanaan. Kegiatan pokok pada tahap ini mencakup peenyusunan Rencana Anggaran Biaya (RAB), pengajuan Surat Permintaan (SPP), dan selanjutnya pelaksanaan kegiatan dilapangan.

Pelaksanaan dalam Pengelolaan Keuangan Desa aadalah rangkaian kegiatan untuk melaksanakan rencana dan anggaran yang telah ditetapkan dalam APBDesa. 
Kegiatan pokok dalam pelaksanaan ini pada dasarnya bisa dibagi menjadi dua bagian yaitu :

$>$ Kegiatan yang berkaitan dengan pengeluaran uang

$>$ Pelaksanaan kegiatan dilapangan

Beberapa ketentuan yang harus diperhatikan dalam pelaksanaan pengelolaan keuangan desa baik penggunaan Dana Desa Maupun Alokasi Dana Desa adalah semua penerimaan dan pengeluaran desa dalam rangka pelaksanaan kewenangan desa dilaksanakan melalui rekening kas desa hal ini tertuang dalam Peraturan Menteri Dalam Negeri Nomor 113 Tahun 2014 pasal 24 ayat 1. Semua penerimaan dan pengeluaran desa harus didukung oleh bukti yang lengkap dan sah (pasal 24 ayat 3 Permendagri 113 tahun 2014). Pengeluaran desa yang mengakibatkan beban APBDesa tidak dapat dilakukan sebelum rancangan peraturan desa tentang APBDesa ditetapkan menjadi peraturan desa (pasal 26 ayat 1 Permendagri 113 Tahun 2014). Pengecualian untuk belanja pegawai yang bersifat mengikat dan operasional kantor yang sebelumnya telah ditetapkan dalam peraturan kepala desa.

Pelaksanaan menjadi bagian terpenting dalam suatu kegiatan atau pelaksanaan program, di Desa Jajaran Baru I dalam pengelolaan ADD dibentuk sebuah tim yang bertugas untuk melaksanakan serta mengelola kegiatan yang didanai oleh ADD. Pengelolaan terkait dengan ADD ini dikelola oleh tim pelaksana atau PTPKD dan Bendahara yang diketuai oleh Kepala Desa sendiri. Baik PTPKD dan Bendahara dipilih langsung oleh Kepala Desa. PTPKD memiliki tugas dilapangan sedangkan untuk bendahara bertugas mengerjakan urusan bidang administrasi.

Pelaksanaan diawali dengan proses pencairan dana yang dilakukan oleh Bendahara Desa melalui Bank yang telah ditunjuk yaitu Bank Sumsel Babel Cabang Megang Sakti, setelah proses pencairan tersebut pihak-pihak dan mitra kerja diundang oleh pihak pemerintah desa dalam rangka mengambil dana yang sesuai pada dokumen rencana kegiatan desa (DRKDesa). Namun dalam proses pengambilan dana tersebut dilakukan secara bertahap. Tahapan yang dilakukan melalui 3 (tiga) tahapan yakni Tahap I pada bulan april sebesar 40\%, Tahap II pada bulan agustus sebesar $40 \%$, dan Tahap III pada bulan oktober sebesar $20 \%$. Proses tahapan perencanaan Bendahara Desa mengalami keterlambatan 3 hari kerja dalam mempersiapkan beberapa dokumen hal ini dikarenakan Sekertaris Desa belum bersedia memverifikasi dan menandatangani dokumen SPP jika seluruh lampiran dokumen belum lengkap. Hal ini sangat berpengaruh terhadap tahapan penatausahaan, pelaporan dan pertanggungjawaban.

Dalam realisasi keuangan ADD tahun 2017 Tahap pertama sebelum APBDes Perubahan untuk penghasilan tetap dan tunjangan sebesar Rp. 190.800.000,(Seratus sembilan puluh juta delapan ratus ribu rupiah), kegiatan operasional kantor desa sebesar Rp. 56.434.500,- (Lima puluh enam juta empat ratus tiga puluh empat ribu lima ratus rupiah), kegiatan operasional BPD sebesar Rp. 15.500.000,- (Lima belas juta lima ratus ribu rupiah), kegiatan operasional RT sebesar Rp. 14.400.000,(Empat belas juta empat ratus ribu rupiah), kegiatan penyelenggara musyawarah desa sebesar Rp. 11.800.000,- (Sebelas juta delapan ratus ribu rupiah), kegiatan pengelolaan informasi desa sebesar Rp. 1.000.000,- (Satu juta rupiah), kegiatan pembinaan kemasyarakatan sebesar Rp. 12.000.000,-- (Dua belas juta rupiah).

\section{Penatausahaan}

Siklus penatausahaan keuangan desa (Dana Desa, Alokasi Dana Desa, Bagi Hasil Pajak dan Retribusi) adalah sebagai berikut : 
a) Siklus penatausahaan keuangan desa dimulai dengan ditetapkannya APBDesa, penatausahaan dilakukan oleh Bendahara Desa

b) Berdasarkan APBDesa, maka pemerintah desa melakukan transaksi keuangan berupa penerimaan kas sebagai sumber pendapatan desa dan melakukan pengeluaran kas berupa belanja untuk menjalankan operasional dan program desa

c) Bendahara desa wajib melakukan pencatatan setiap transaksi penerimaan kas dan pengeluaran kas berdasarkan bukti-bukti transaksi keuangan (kas masuk dan kas keluar) yang sah terutama Surat Permintaan Pembayaran dan Bukti Penerimaan Kas, mencatatnya dalam buku-buku kas (buku kas umum, buku kas pembantu pajak dan buku bank)

d) Bendahara desa wajib melakukan penutupan (tutup buku) pada setiap akhir bulannya dari masing-masing buku kas tersebut dan menjadikannya sebagai laporan ke kepala desa

e) Bendahara Desa memposting setiap transaksi yang dicatat dalam buku kas ke masing-masing akun/rekening yang ada di buku besar

f) Pada saat akan menyusun laporan keuangan, baik semesteran maupun tahunan, bendahara desa harus menyusun neraca saldo yang merupakan ringkasan saldo dari setiap akun/rekening yang ada di buku besar

g) Bendahara Desa menghitung dan melakukan penyesuaian terhadap akunakun/rekening-rekening yang terkait dengan aset lancar sebagai tahap penyusunan laporan kekayaan milik desa

h) Bendahara Desa wajib mempertanggungjawabkan uang dengan menyusun laporan keuangan sebagai laporan pertanggungjawaban

i) Laporan pertanggungjawaban disampaikan setiap bulan kepada kepala desa paling lambat tanggal 10 setiap bulan berikutnya

j) Penatausahaan penerimaan dan pengeluaran wajib menggunakan buku kas umum, buku kas pembantu pajak dan buku bank.

Dalam tahapan pelaksanaan telah terjadi keterlambatan beberapa hari kerja dalam mempersiapkan dokumen pencairan dana, hal ini berpengaruh terhadapan tahapan penatausahaan yaitu proses yang berkelanjutan dari tahapan pelaksanaan. Penyebabnya adalah teknis dalam mempersiapkan laporan pertanggungjawaban memerlukan tingkat ketelitian yang tinggi agar tidak terjadi kesalahan dalam penjumlahan angka-angka yang ada pada laporan anggaran tersebut.

\section{Pelaporan}

Berdasarkan Peraturan Menteri Dalam negeri Nomor 113 Tahun 2014 tentang Pedoman Pengelolaan Keuangan Desa dalam ketentuan umum pasal 1 ayat 10 menyatakan bahwa Alokasi Dana Desa (ADD) adalah Dana perimbangan yang diterima kabupaten/kota dalam Anggaran Pendapatan dan Belanja Daerah Kabupaten/kota setelah dikurangi Dana Alokasi khusus. Pada bagian keempat pelaporan pasal 37 ayat 1 Kepala Desa menyampaikan laporan realisasi pelaksanaan APBDesa kepada Bupati/Walikota berupa :

a. Laporan Semester pertama

b. Laporan semester akhir tahun

Ayat 2 menyatakan Laporan semester pertama sebagaimana dimaksud pada ayat (1) huruf a berupa laporan realisasi APBDesa, ini sudah termasuk laporan realisasi Alokasi Dana Desa karena ADD dimasukan ke dalam APBDesa sebagaimana dimaksud pada ayat (1) huruf a disampaikan paling lambat pada akhir 
bulan juli tahun berjalan, dan ayat 4 berbunyi laporan semeste akhir tahun sebagaimana dimaksud pada ayat (1) huruf b disampaikan paling lambat pada akhir bulan januari tahun berikutnya.

Pelaporan merupakan salah satu bentuk pertanggungjawaban yang dilakukan Pemerintah Desa Jajaran Baru I khususnya dalam pengelolaan ADD ini. Di Desa Jajaran Baru I sistem pelaporannya dilakukan melalui dua bentuk yakni secara subtantif dan normatif. Subtantifnya pemerintah desa melakukan pelaporan setiap 34 bulan sekali yakni melalui musyawarah yang dilakukan oleh pemerintah desa dengan mitra kerjanya. Dengan adanya pelaporan tersebut akan mempermudah dalam proses evaluasi atas pelaksanaan program atau kegiatan yang dibiayai oleh ADD. Sedangkan secara normatifnya pemerintah desa berkewajiban melaporkan setiap kegiatan atau program yang dibiayai oleh ADD dengan membuat sebuah laporan Surat Pertanggung Jawaban (SPJ) kepada Kabupaten dengan persetujuan dan melewati Kecamatan. Dalam laporan tersebut berisi daftar perencanaan program atau kegiatan yang dibiayai oleh ADD hingga bukti-bukti dokumentasi dan apapun yang berhubungan dengan program yang dibiayai ADD. (Bentuk SPJ terlampir)

\section{Pertanggungjawaban}

Bentuk pertanggungjawaban dalam pelaksanaan pengelolaan keuangan desa dalam hal ini sudah termasuk laporan realisasi penggunaan ADD di Desa Jajaran Baru I Kecamatan Megang Sakti yaitu semua transaksi penerimaan dan pengeluaran keuangan desa, harus dipertanggungjawabkan oleh Bendahara Desa sebagai berikut :

a) Membuat laporan pertanggungjawaban pengeluaran dengan melampirkan buku kas umum, buku kas penerimaan pajak, buku bank, laporan realisasi pelaksanaan APBDesa, kwitansi, surat permintaan pembayaran (SPP) dari pelaksanaan kegiatan, pernyataan tanggungjawab belanja dari pelaksanaan kegiatan, lampiran bukti transaksi yang dilaksanakan oleh pelaksana kegiatan, bukti pajak, surat tugas, surat perintah perjalanan dinas dan laporan perjalanan dinas, ijazah/sertifikat (untuk belanja pelatihan, bimtek atau kursus bagi peningkatan kapasitas aparatur, foto visual (bila ada pekerjaan fisik dan berita acara serah terima pekerjaan

b) Laporan pertanggungjawaban harus diserahkan copy satu rangkap kepada Kecamatan Megang Sakti, dan asli satu rangkap sebagai arsip pemerintah desa

c) laporan disusun untuk mempertanggungjawabkan tahapan sebelumnya dan bulan sebelumnya

d) laporan pertanggungjawaban diserahkan bersamaan dengan penyerahan SPP APBDesa tahap II (pertanggungjawaban tahap I) dan tahap III (Pertanggungjawaban tahap II) SPP penghasilan tetap dan tunjangan Kepala Desa dan Perangkat Desa, serta tunjangan BPD bulan berkenaan (Pertanggungjawaban bulan sebelumnya)

e) pertanggungjawaban tahap III dan pertanggungjawaban bulan Desember diserahkan paling lambat tanggal 31 Januari tahun berikutnya.

\section{Pembinaan dan Pengawasan}

Tujuan pembinaan dan pengawasan dalam hal ini Inspektorat terhadap pengelolaan keuangan desa mulai dari pengelolaan Alokasi Dana Desa (ADD) maupun Dana Desa (DD) yaitu untuk mengetahui apakah pelaksanaan pengelolaan 
keuangan desa telah sesuai dengan ketentuan yang berlaku, sebagai dasar penilaian pelaksanaan pengelolaan anggaran yang telah memenuhi prinsip ekonomis, efisien dan efektif serta untuk penilaian kehandalan pengendalian intern dalam pengelolaan keuangan desa hal ini telah tertuang dalam Peraturan Menteri Dalam Negeri Nomor 113 Tahun 2014 tentang pengelolaan Keuangan Desa.

Ruang lingkup pengawasan ini terdiri dari Administrasi Pemerintahan Desa dan Urusan Pemerintahan Desa. Pengawasan dilakukan terhadap Kebijakan Desa, Kelembagaan Desa, Keuangan Desa dan Kekayaan Desa. Hasil pemeriksaan kegiatan pengawasan yang dilakukan oleh Pejabat Pengawas Pemerintah pada Inspektorat tersebut harus ditindaklanjuti Pemerintah Desa sesuai dengan rekomendasi. Pemerintah Desa yang tidak menindaklanjuti rekomendasi dimaksud akan dikenakan sanksi sesuai dengan ketentuan peraturan perundang-undangan.

Bentuk pengawasan Inspektorat Kabupaten kepada Pemerintah Desa yaitu kegiatan pemeriksaan, kegiatan monitoring dan kegiatan evaluasi, hasil pemeriksaan dan evaluasi tersebut akan dilaporkan kepada Bupati

E. KESIMPULAN DAN SARAN

1) Kesimpulan

a. Tahapan perencanaan, pelaksanaan, penatausahaan, pelaporan dan pertanggungjawaban serta tahapan pembinaan dan pengawasan. Dimana semua tahapan telah dilaksanakan Pemerintah Desa sebagai dasar komitmen Pemerintah Desa dalam menyelenggarakan pengelolaan keuangan khususnya pengelolaan ADD.

b. Adanya keterlambatan dalam tahapan pelaksanaan dalam proses pencairan disebabkan beberapa dokumen untuk pencairan dana belum dilengkapi oleh Bendahara Desa sebagai Tim Pelaksana PTPKD yaitu lampiran bukti transaksi pengeluaran dana, pernyataan tanggungjawaban belanja dan Surat Permintaan Pembayaran yang belum di verifikasi oleh Sekretaris Desa. Dalam memenuhi tugas dan tanggung jawab sebagai Sekretaris Desa tidak bersedia menandatangani dokumen jika dokumen tersebut belum lengkap. Keterlambatan proses pencairan dana berpengaruh terhadap tahapan penatausahaan, pelaporan dan pertanggungjawaban hal ini dikarenakan batas waktu penyampaian laporan pengelolaan ADD melebihi tanggal yang sudah ditetapakan yaitu pada tanggal 10 setiap bulannya. Setiap tahapan penatausahaan, pelaporan dan pertanggungjawaban melewati batas waktu yang ditentukan yaitu 7 hari kerja setiap bulannya.

c. Dalam tahapan pembinaan dan pengawasan pengelolaan ADD telah dilaksanakan dan telah sesuai berdasarkan Peraturan Menteri Dalam Negeri Nomor 113 Tahun 2014 tentang Pengelolaan Keuangan Desa dan Keputusan Bupati Nomor 157/KPTS/DPMD/2017 tentang Penetapan Besaran Alokasi Dana Desa Kabupaten Musi Rawas Tahun 2017.

2) Saran

a. Perlunya dispilin administrasi oleh Bendahara Desa dalam mempersiapkan seluruh dokumen pada tahap pelaksanaan dalam proses pencairan dana, serta perlunya penatausahaan yang baik dan informatif sehingga mempermudah Bendahara Desa dalam membuat laporan keuangan ADD dan mempertanggungjawabkannya dengan tepat waktu dan tidak ada lagi 
keterlambatan dalam proses pelaporan dalam pertanggungjawaban ke Pemerintah Kecamatan Megang Sakti dan Pemerintah Kabupaten Musi Rawas

b. Peningkatan kinerja dan program yang lebih baik oleh Pemerintah Kabupaten melalui pembinaan pemerintah desa sehingga dapat meningkatkan kualitas pemerintahan desa itu sendiri, serta lebih menjalinan komunikasi yang lebih erat lagi antara Pemerintah Desa, Kecamatan dan Pemerintah Kabupaten guna meningkatkan penyelenggaraan Pemerintahan yang lebih baik lagi.

\section{DAFTAR PUSTAKA}

Apriliana Somborarak. 2014. Evaluasi Program Alokasi Dana Desa Kabupaten Kutai Kartanegara. Jurnal IImu Pemerintahan, 2(2):2704-2715

Chabib Soleh dan Heru Rochmansjah, 2015. Pengelolaan Keuangan Desa. Bandung: Fokusmedia.

Danang Sunyoto, 2013. Methodologi Penelitian Akuntansi. Jakarta: PT. Sentosa.

Eni Dwi Susliyanti. 2016. Transparansi dan Akuntabilitas Alokasi Dana Desa Kabupaten Bantul. Forum Keuangan Bisnis, 5(5):261.

Informasi Penyelenggara Pemerintah Desa Jajaran Baru I Tahun 2017.

Laporan Keterangan Pertanggung Jawaban Desa Jajaran Baru I tahun 2017.

Peraturan Bupati Kabupaten Musi Rawas Nomor 157/KPTS/DPMD/2017 Tentang Penetapan Besaran Alokasi Dana Desa Tahun 2017.

Peraturan Bupati Kabupaten Musi Rawas Nomor 5 Tahun 2012 Tentang Tata Cara Pembagian Dan Penetapan Rincian Dana Desa Setiap Desa Di Kabupaten Musi Rawas Tahun Anggaran 2017.

Peraturan Bupati Musi Rawas Nomor 4 Tahun 2017 Tentang Pedoman Teknis Pengelolaan Belanja Alokasi Dana Desa Dan Dana Desa Kabupaten Musi Rawas Tahun 2017.

Peraturan Menteri Dalam Negeri Nomor 113 Tahun 2014 Tentang Pedoman Pengelolaan Keuangan Desa.

Peraturan Menteri Desa, Pembangunan Daerah Tertinggal dan Transmigrasi RI Nomor 22 Tahun 2016.

Peraturan Pemerintah RI Nomor 8 Tahun 2016 Tentang Perubahan Kedua Atas Peraturan Pemerintah Nomor 60 Tahun 2014 Tentang Dana Desa Yang Bersumber Dari Anggaran Pendapatan Dan Belanja Negara.

Undang-undang Nomor 6 Tahun 2014 Tentang Desa. 